\title{
Speaking up, leaving or keeping silent: racialised employees in the Swedish elderly care sector
}

\author{
Alireza Behtoui, Kristina Boréus, Anders Neergaard and Soheyla Yazdanpanah \\ Journal Article
}

\section{Tweet}

N.B.: When citing this work, cite the original article.

Original Publication:

Alireza Behtoui, Kristina Boréus, Anders Neergaard and Soheyla Yazdanpanah, Speaking up, leaving or keeping silent: racialised employees in the Swedish elderly care sector, Work, Employment and Society, 2016. (), pp.1-18.

http://dx.doi.org/10.1177/0950017016667042

Copyright: SAGE Publications (UK and US)

http://www.uk.sagepub.com/home.nav

Postprint available at: Linköping University Electronic Press

http://urn.kb.se/resolve?urn=urn:nbn:se:liu:diva-134451

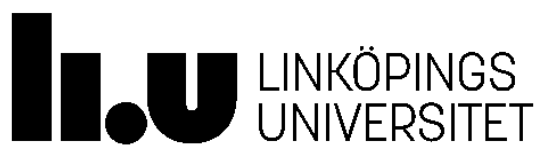




\title{
Speaking up, leaving or keeping silent: racialised employees in the Swedish elderly care sector
}

\begin{abstract}
When encountering problems and dissatisfaction in the workplace, employees may choose between three strategies: voice, exit or silence. Using survey data and interview material from a study of employees in an elderly care organisation in Sweden, this article investigates the workers' perceptions of the eligibility and prospects of these strategies and which individual characteristics and situational factors might affect them. The focus is on racialised workers (operationalised through their region of birth) who, according to earlier studies, are less likely than other employees to choose voice behaviour. Contrary to some earlier studies, the results here attribute such a propensity to the importance of power differences across 'racial hierarchies' rather than to differences in cultural values. Individuals in this (racialised) category have a lower occupational status, earn less and experience less favourable relationships with their managers.
\end{abstract}

\section{Keywords}

Exit, voice, silence, racialised workers, Sweden 


\section{Introduction}

This article is about the different ways in which employees respond to problems and dissatisfaction in the workplace - choosing either voice (attempts to change), exit (leaving the organisation) or silence (refraining from any attempt to change conditions). It looks at how different categories of employees perceive strategies challenging the status quo in their workplace and how variations between categories may be explained.

As Morrison (2011) recalls, earlier research demonstrated that workers with a minority background tend to be less engaged and believe in voice behaviour to a lesser extent than other workers. However, 'The reasons for these differences remain open to speculation' (2011: 393). Some studies interpret such differences as the result of variations in cultural values. This article contributes to the existing literature by providing a relational power perspective on why racialised employees differ in their perceptions of voice strategies. Using survey data and interview material from a study of employees in an elderly care organisation in Sweden, the article investigates which individual characteristics and situational factors affect the workers' perceptions when choosing from the available strategies. The article argues that the lack of power experienced by racialised employees is the most likely explanation for their comparatively low propensity to believe in voice behaviour. Another finding of this research is that being an employee from Africa, Asia or Latin America meant, to a higher degree than for others, having a more negative view of the voice climate and not that this category of workers planned for exit. This might, therefore, be explained by the more precarious position in the labour market of these employees.

The article seeks to answer three research questions. Firstly, what individual factors and features of the workplace (situational factors) have an impact on employees' perceptions of the voice climate of their workplace? Secondly, what individual and situational factors may have an impact on employees' intention to exit their workplace? Thirdly, can the individual and situational factors found to have an impact be related to power at the workplace and in what way?

The elderly care sector is a good choice for studying employees from different backgrounds. While initially mainly feminised by native women, the increasing demand for elderly care within an ageing population, in combination with low-status, tough working conditions and low pay, has gradually transformed the sector into a labour market niche for foreign-born workers in more vulnerable labour market positions (Sörensdotter 2008). Care of the elderly in Sweden, with its workforce consisting of a majority of women and thus a minority of men, together with a comparatively high proportion of foreign-born workers, may provide important insights into the role of class and gender and the consequences of racialisation on employees' perceptions of, and choices between, voice, exit and silence.

The article is structured as follows: the next section presents the theoretical framework. Then the study is contextualised within the elderly care sector. Subsequent sections deal with data gathering methods and the presentation of measurements. The main part of the article presents the results from the survey and interviews. In the final section, the answers are summarised emphasising the importance of power differences and racialisation for the workers' choice between voice, exit and silence.

\section{Theoretical framework: voice, exit, silence, power and racialisation}

The concept of voice goes back to Hirschman's (1970) seminal work which assumes that an organisation's members signal their concerns by either exit or voice when dissatisfied with either the unfavourable treatment they receive, the decision making processes or the work 
environment. He defines 'voice' as 'any attempt at all to change rather than escape from an objectionable state of affairs' (1970: 30). According to Marchington and Wilkinson (2005), there are two different forms of employee voice behaviour: representative/collective/formal and direct/individual/informal. Examples of the former type are the trade union voice, regular staffmanagement meetings and quality circles. Examples of the latter type are individual (one-onone) interactions between employees and their superiors and workplace suggestion schemes.

'Exit' refers to employees leaving the organisation. A precondition for the choice of voice behaviour is the perceived efficacy of that voice - that is, the belief that management will listen and take appropriate action. If not, then, in some situations, 'Exit will be a reaction of last resort after voice has failed' (Hirschman, 1970: 37). An exit is less likely, however, if there is no other job accessible. Those who have paid dearly to enter a workplace and those for whom exit demands great sacrifice will be reluctant to quit (Hirschman, 1970). Thus, individuals may choose to remain in the workplace even though they are dissatisfied, either because moving is too difficult or out of loyalty. Loyalty is about overall identification with and/or emotional attachment to the organisation. 'The presence of loyalty makes exit less likely' (Hirschman 1970: 77).

When neither voice nor exit are applied, even though employees are dissatisfied, they might 'suffer in silence' (1970: 38). In other words, silence reflects employees' not perceiving exit or voice as salient alternatives. As Morrison (2011) states, in such a situation silence indicates a sense of resignation or futility, the feeling that voice will not accomplish anything. According to Donaghey et al. (2011: 9-10), silence may also be 'a product of cynicism, distrust or a defensive position in the frontier of control ... a survival strategy, where employees with low attachment to the organisation "mentally withdraw" to cope with work's more unpleasant aspects'. In this interpretation, 'structurally based issues of power, authority and control' are emphasised.

Wilkinson and Fay (2011) identify two strands of literature that deal with the concept of voice. In the first strand, scholars use the concept to refer to management agendas that are concerned with increasing employees' commitment and contribution to the organisation (Strauss, 2006: 778). The second strand emphasises the centrality of power in using voice to encourage the participation of employees in workplace decision making and organisation (Kanter, 1993). For a comprehensive literature review of the concept, see Brinsfield (2009).

'Power' is defined in many different ways in the literature. One basic strand of definition focuses the position of individuals or groups within social settings. Along with this way of understanding power, which is often used within organisational research, 'positional power within an organisation [includes both] control of resources, outcomes, and behaviour [and] interpersonal-social status and dominance' (Islam and Zyphur, 2005: 94). According to Acker (2006: 443), power in an organisation contains: 'control over goals, resources, and outcomes'. She also includes several other dimensions in organisational power that are not clearly positional, such as 'pay and other monetary rewards; respect; and pleasures in work and work relations' (2006: 443). Power relations in the workplace are crucial for an individual's choice of strategy. As Morrison et al. (2015) write, employees who feel that they lack power in their workplace will be much more likely to remain silent compared to those who feel more powerful.

One dimension of power relations in work organisations that may affect the various propensities to select voice is the active presence of trade unions. As Freeman and Medoff (1984) mention, the 'collective voice-institutional response face' of trade unions enables workers to channel their dissatisfaction into improved workplace conditions. Thus, improved personnel policies (as a result of pressure from the unions) can, in turn, lead to lower levels of resignation (exit). 
Some categories of employee are less likely than others to be found in powerful positions. Many studies emphasise the disadvantage of women and racialised workers (Acker, 2006; McCall, 2001). The Swedish labour market is characterised by substantial workplace segregation, with the foreign-born more often being employed in subordinate, monotonous low-payed jobs (Behtoui, 2006). The way in which immigrant employees are systematically disadvantaged in relation to native employees in certain workplaces has also been studied (see, for example, Boréus and Mörkenstam, 2015). There are, however, important differences between the foreign born who originate from the various parts of the world. Earlier Swedish studies confirm that relative to others, individuals from Africa, Asia and Latin America with similar levels of productivity, have an inferior status in terms of employment or wages, and are more likely to suffer from discrimination (Behtoui and Neergaard, 2010).

To explain this disparity based on country of birth, the concept of 'racialisation' has been employed in the literature to capture socially constructed notions of 'race' that enter into social and economic relations (see, for example, Miles 1993; Solomos 2002). Racialisation highlights the relational processes in which the use of phenotypical traits and references to culture are used negatively to distinguish some groups in a way that creates a racialised 'Other' and, at the same, a silently racialised 'We'. The constitution of such a social identity 'is an act of power' (Laclau, 1990: 31). These dynamics of racialisation affect workplace relationships through a variety of mechanisms both horizontally (among the employees) and vertically (employee-management) (Acker, 2006). In line with the discussion above, the term 'racialised' is used in this article to refer to people who tend to be defined in a particular category based on their 'physical characteristics, culture, and historical domination and oppression, justified by entrenched beliefs' (Acker, 2006: 444). In the Swedish context, as already mentioned, foreign-born workers from Africa, Asia and Latin America (and their children) tend to be racialised to a higher degree than others (Behtoui, 2006).

\section{Context of the study}

The study was carried out using a mixed-methods design that included a survey, semi-structured individual interviews and participant observation. It was conducted in a number of publicly and privately run residential elderly care institutions in a large Swedish city.

Elderly care occupies a central place within the Swedish welfare system (Gustafsson and Szebehely, 2007). Since the 1990s, Sweden has witnessed an ideological and political change aimed at reducing the costs of welfare services, under the slogan 'Efficiency, Flexibility and Freedom of Choice'. This was the beginning of the implementation of market ideas and rationalities, known as New Public Management (NPM) in welfare services generally and in elderly care particularly (Bouckaert and Pollitt, 2011; Meagher and Szebehely, 2013).

In 2012, more than one in five beds in residential elderly care institutions was provided by private businesses (Erlandsson et al., 2013). Many municipalities now outsource residential elderly care, meaning that private care providers and the municipalities' own providers have to compete for the contracts to run particular institutions, a process that is repeated every four years (Erlandsson et al., 2013). This model is used by the city in which our study took place.

Working in Swedish residential elderly care is comparatively poorly paid, even though the staff undertake tasks which are physically, emotionally and mentally demanding (Sörensdotter, 2008). At the same time, the NPM-influenced changes have increased workers' stress loads and feelings of insecurity. Gustafsson and Szebehely (2007) found a clear deterioration in staff working conditions and environment in several aspects of the elderly care they were paid to provide. Trade union studies also show a significant decline in job security. Around 60 percent 
of respondents in the residential elderly care sector considered that the institutions where they worked were understaffed (Kommunal, 2012; Wall, 2013).

Several of our informants reflected on the changes to the system, not least the diminishing resources. As expressed by a front-line manager (Informant 16) with many years of experience in the elderly care sector, 'In 1998, when I started working here, we absolutely had a lot more resources'. As one example of the consequences of resource reduction she went on to say, 'When we want to recruit [extra] personnel for the night shift, we have to do without the cleaner and ask the staff to clean instead'. According to an experienced assistant nurse, they were now responsible for 'washing our own working-clothes ... where should we find the time? It is mostly taken up by the elderly residents ... then we have less and less time for the residents and more and more time given over to this kind of work' (Informant 20). Informants sometimes related their expanding workload to the competition between the municipality and the privatesector actors referred to above (Informants 14 and 30). The importance of keeping costs down was emphasised at several workplace meetings we attended and this competition was often mentioned. As Informant 23 put it:

There is understaffing. This is the case today both in the municipal businesses and in the private ones. The municipality used to be better before it started to compete and make a profit itself. This leads to the same way of thinking as in private businesses.

Some of the municipally employed informants also reported that the competition for contracts caused insecurity, since they did not know if the municipality or a private company would run the unit in which they would work after the next public procurement. What would a change mean to them - perhaps changed working conditions or even losing their job (Informants 8, 12 and 15)?

The context described above confirms that the elderly care sector provides a typical environment in which the breeding of dissatisfaction drives employees to think about choosing between the options of voice, exit or silence.

\section{Data}

The main results reported below were drawn from the survey element of the study. They are discussed together with extracts from the semi-structured interviews (based on a stratified selection of employees from different workplaces and holding various positions - a total of 34 individuals).

The survey was carried out in 12 residential elderly care institutions in a large Swedish municipality. A questionnaire survey was conducted in Spring 2013. Employers in the public and private institutions provided the names, telephone numbers and addresses of the employees. A telephone survey of these individuals was conducted in collaboration with Statistics Sweden (SCB 2015). Alongside the results of the questionnaire, further information was obtained (such as the respondent's age, educational level, gender and birthplace) from the population register of Statistics Sweden.

Of the total population surveyed by Statistics Sweden (510 individuals - all employed in these institutions according to the files of the employers), 304 people, or about 61 percent, responded. Comparing the final sample with non-respondents shows that they do not significantly differ from one another in terms of age, gender or region of birth. In this study, 289 employees were included, mainly nurses and nursing assistants/assistant nurses, who work directly in the care of elderly people in the divisions. ${ }^{1}$ Nursing assistants were of an older generation, had compulsory education (nine years) or less and were called vårdbiträden. Most assistant nurses (undersköterskor) belonged to a younger generation and graduated from 
vocationally oriented secondary-school programmes on health and nursing (Omvårdnadsprogrammet) with a three-year upper-secondary-school education. The nurses had at least three years' university education.

\section{Measures}

In some earlier studies, voice is operationalised in terms of the presence of different avenues for speaking up. Holland et al. (2011), for example, use the existence of a union in the workplace and other two-way communication channels (e.g. regular meetings between management and staff) as indications of voice. During our fieldwork, we found that almost all channels of voice (from union presence to workplace surveys) existed in the workplaces we studied, although our observations of employees' perceptions, and our survey results, raised questions concerning both the efficiency and the efficacy of these channels. Consequently, the mere presence of different avenues for voice was not a good enough measure.

Developments in voice measurement emphasise the quality and features of voice rather than the presence of certain channels. Liang et al. propose a two-factor construct for the reporting of employees' voice: promotive and prohibitive voice. The promotive aspect of voice signifies the 'expression of ways to improve existing work practices and procedures' (2012: 71). The prohibitive aspect of voice, on the other hand, is the concern expressed about 'existing or impending practices, incidents or behaviours that may harm the organization' (2012: 72). Furthermore, as Milliken et al. (2003) underline, voice efficacy (the employees' belief that voice would make a difference) is a key dimension of the workplace's climate for voice.

To measure the three aspects of promotive voice, prohibitive voice and voice efficacy as perceived by the employees, we asked them whether: a) they had the possibility to affect schedules and practices; b) they felt that they could convey critical standpoints about practises in the workplace to their managers and c) their suggestions for changes and improvements were taken seriously by managers. These items were measured on a scale ranging from 1 to 4 , representing: $1=$ 'Yes, to a high degree', 2 = 'Yes, to a certain degree', $3=$ 'No, not much', and $4=$ 'No, not at all'. Based on the answers to these three questions (as indicators of perceptions of voice climate), an index was constructed for each individual. We first reversed the scales (a higher value denotes more a positive perception of voice climate) and then, with an exploratory factor analysis (EFA) with principal component methodology, created a continuous variable labelled Voice, which has a mean equal to 0, a minimum of -3.2 and maximum of 6.4 and 53 different values.

To measure the respondents' openness to exit, we asked them about their plans for the next two years. The group who we assumed would choose exit rather than voice or silence were those who answered that they were going to continue working in the care sector but not in that specific workplace.

The survey data, in addition, included individual and demographic information which we used as control variables. The categories of foreign born in this study were generated by country of birth, reflecting practices of racialisation. First, employees born in Sweden of two nativeborn parents (the reference group); second, foreign-born workers from North-Western Europe and North America; third, those born in Eastern European countries; and finally, those born in Africa, Asia or Latin America).

Other control variables for the individual factors in our analysis were gender (men $=1$ ), labour market experiences (number of years), the occupational status of employees (constructed on the basis of detailed answers by staff about their position and tasks by using the prestige ranking of Svensson and Eriksson, 2009, for Sweden), sector (private sector $=1$ ), full/part-time work (percent) and job security (permanently employed $=1$ ). 
Furthermore, we included several factors that previous research has shown to be related to voice behaviour. As Freeman and Medoff (1984) suggest, union membership might enhance the individual employee's perception of voice. Despite the decline in trade union membersihp in Sweden from its once very high level, the percentage of trade union density is still above 80 percent (Kjellberg, 2015: 73). These members are not, however, all active participants in union activities.

The voice literature has highlighted, the importance of organisational context (Morrison, 2011). The variable Superior was constructed with the two indicators below in an exploratory factor analysis to assess how employees perceived their relationship with their senior managers. Our measure for this relationship was based on a four-item scale that asked respondents: 'Do you trust your senior manager?' and 'Do you have a good relationship with your manager?'.

According to the literature, having supportive co-workers is another important contextual factor in employees' willingness to express any suggestions, complaints or concerns they may have related to their workplace (Parker et al., 2006). In order to measure the impact of the relationship between our respondents and their co-workers, we constructed a variable labelled Co-worker using data from the questionnaire in an exploratory factor analysis: the number of close friends among respondents' teammates and their responses to the questions 'Do your workmates care if you feel down at work?', 'Do your workmates help you when you have too much to do?', and 'Would you describe your workplace as conflict-ridden?'.

\section{Results}

\section{Descriptive data}

The majority of the employees in this study were Sweden-born women who were working as assistant nurses and nursing assistants in publicly run residential elderly care institutions, although more than 13 percent of the respondents were working in privately run institutions Employees had a mean age of 46 years $^{2}$ and about 11 percent of the staff were men. As shown in Table 1, around 66 percent of our sample was born in Sweden, 3 percent in North-Western Europe or North America, 5 percent in Eastern European countries and 26 percent in Africa, Asia or Latin America.

While the average general work experience of the respondents was 21 years, they had, on average, worked in elderly care services for more than 18 years. Among those who participated in this survey, about 75 percent had a full-time position and a majority were in permanent employment. Comparing these figures with other statistical sources ${ }^{3}$ and data from our participant observation, we can see that the percentage of those without a permanent position and with a part-time job was higher compared to the list provided by the employers, many of those in these categories of employees were not included on this list. This means that employees in precarious work situations and those with part-time contracts are under-represented in our sample. In other words, we have surveyed the employees who presumably hold the most secure positions, and who are thus the most likely to be able to confront workplace problems efficiently. If these latter hesitate to use the voice option, then employees in more precarious employment might be even more hesitant to choose that option.

As expected from earlier research, employees from Africa, Asia and Latin America in our study were found to be working in less-powerful positions than others (Autor A, 2006). Their 
subordinated position was indicated by, among other things, their significantly lower mean salaries (adjusted for working hours) and occupational position. Even after we controlled for educational level and work experience, we found that these employees had lower salaries and lower occupational status than others (not shown here, but available from the authors on request). Thus, being born in Africa, Asia or Latin America appeared to be an important reason for having a lack of power in the workplace, a disparity that Acker labels as 'racial relations of inequality' (2006: 441).

\section{Table 1 here}

\section{The impact of employees' characteristics and working conditions on their views on the} voice climate

To examine the impact of the individual characteristics of employees and their situational factors (i.e. employees' 'working conditions' and the 'organisational context' of their workplaces) on their perception of the voice climate, a linear regression analysis (OLS) was conducted and the results are given in Table 2.

Morrison (2011: 393), in a survey of previous research in the field, wrote that ethnic minorities believe or engage less often in voice behaviour than 'whites'. The reason for this difference is not obvious and 'remains open to speculation'. As our results in Model 1 of Table 2 demonstrate, workers with a background from Africa, Asia or Latin America tended to be significantly less convinced than others of the voice climate being favourable, even after controlling for their occupational status - a factor of importance (see below).

Earlier studies show mixed results concerning the effect of gender on voice (Burke and Cooper, 2013). As shown in Model 1, no significant gender difference concerning perceptions of voice climate was observable among the individuals in our sample within this womendominated sector of the Swedish labour market. Previous research indicates that the situation might be different in men-dominated sectors (Boréus and Mörkenstam, 2011).

Some studies suggest that greater labour market experience is associated with a stronger belief in voice (Morrison, 2011). Our results, however, did not support this hypothesis. Previous research has also demonstrated that there is a positive relationship between an individual's power position in the workplace and belief in voice (Burke and Cooper, 2013). The reason, suggest Detert and Edmondson (2011), is that those in the lower ranks of the hierarchy believe that their suggestions and ideas will not be taken seriously and that they may be punished for speaking up. Our results, in line with this earlier research, confirmed that employees' 'occupational status' had a statistically significant effect on their perception of the workplace voice climate i.e. a higher rank in the organisation is positively associated with a stronger belief in voice.

Freeman and Medoff (1984) focus on union membership as the most effective mechanism of voice, because unions can afford employees a degree of protection from reprisals by the employers when an individual employee has revealed his or her grievance (Allen and Tuselmann, 2009). Although about 80 percent of employees in Sweden are members of trade unions, not all are active participants in their union's activities, with only around 28 percent of our respondents stating that they played an active part. There was, however, no statistically significant association between activity in the trade union and perceptions of the voice climate. As Donaghey et al. (2011: 57) put it, the union as a voice mechanism may exist but it is weak or ineffectual' (for other explanations linked to workplace representatives and the character of workplaces in the Swedish context, see Kjellberg, 2015). 
Previous research has considered the impact of the 'working conditions' of employees and 'the organisational context' (Morrison et al., 2011) to be among other factors that affect the perceptions of employees on voice climate.

We cannot observe any statistically significant results for variables related to 'working conditions' (working in the private or the community sector, holding a part- or full-time job and being permanently or temporarily employed), although this may be due to the earliermentioned bias in our sample. In Models 4 and 5 in Table 2 we show the results of the impact of 'organisational context' - that is, of employees' relationships with their managers and coworkers. Earlier studies (see, for example, Detert and Edmondson, 2011) have shown that there is a positive association between workers' belief in and managers' openness to voice - i.e. the manager's tendency to listen to staff and to show an interest in their critiques and ideas and to give fair consideration to their suggestions. Our results, shown in Model 4, confirmed that the quality of a worker's relationship with the manager was significantly and positively related to employees' beliefs regarding voice. Related to this issue, one assistant nurse who had migrated from a country outside Europe or North America (Informant 24), told us:

Much depends on the manager. We received a lot of appreciation from our former manager. She was really nice and fair to all. For her, there were no differences between immigrants and Swedes. All were equal for her, while the present manager had her own favourites.

When asked how the former manager conducted staff meetings, she added: 'She used to ask everyone round [the table] about her/his opinion. During each meeting, we talked about what we thought and what should be done'.

According to Detert and Burris (2007), when the superiors in an organisation are approachable and listen to the employees' ideas and criticisms, are interested in their input and are open to their ideas and suggestions, then employees report a greater likelihood of voicing (see also Wilkinson, 2012).

As shown in Table 1, workers from Africa, Asia and Latin America reported the worst relationship with their managers. This was also reflected in the interviews. Informant 24 was convinced that she had been denied further training when it was her turn to attend the course '[b]ecause I'm an immigrant'. A young assistant nurse from this group told the interviewer:

The managers treat us differently. It's very clear ... It seems to me that it's really harder for us than for the Swedes. ... I didn't notice that before but it becomes more and more obvious. E. [the native team leader] says to me on the phone: 'You foreigners, misunderstand!' (Informant 17).

A native colleague of this care worker confirmed this, stating that '[w]e are treated in different ways, I don't think that E. deals with me as she does with others ... some people are harder hit ... I don't think Swedes are treated equally badly' (Informant 18). Another native employee noticed discriminatory behaviour from another high-ranked person: ' ...then there was an immigrant who was a Muslim and she was, sort of, sneered at by a nurse (...) she [the nurse] used to say nasty things to her...' (Informant 2).

Having supportive co-workers has likewise been identified as an important facilitator of voice. Parker et al. (2006) suggest that, when workers feel that their relationship with their coworkers is characterised by trust, they gain more confidence in their own abilities. Furthermore, they add, such trust encourages them to suggest ideas concerning matters above and beyond their own tasks or to risk voicing critical views. When we asked about the possibilities for employees to influence working conditions, one experienced assistant nurse answered: 
Yes... but if everybody cooperates ... it's hard, but if all staff collaborate with each other and say the same thing, then it's possible to have an effect [on the work environment] and change the things that are not good (Informant 9).

The results in Table 2, Model 5 show that what this employee expressed was part of a pattern.

\section{Table 2 here}

One interesting outcome of our analysis is that the relationship of a worker with his/her supervisor and co-workers was a partial mediator of the association between the variables 'occupational status' and 'region of birth' on the one hand and our output variable ('employees' perceptions of voice climate') on the other. When these variables were taken into account in Models 4 and 5, the differences regarding belief about the voice climate decreased steadily and significantly in each model between employees from Africa, Asia and Latin America and others, and between employees in the higher ranks of the hierarchy and others. This means that these 'organisational context' variables can partially explain the lesser belief in the voice climate of those in the lower ranks of the organisation and employees who run the greatest risk of being racialised.

\section{The impact of employees' characteristics and working conditions on their likelihood to} plan for exit

In this section we examine the factors that affected employees' plans for the future and particularly for leaving the workplace (Exit). As Hirschman (1970: 37) states, 'In some situations, exit will be a reaction of last resort after voice failed'.

About 22 percent of our respondents stated that they were going to continue working in the care sector but not in that specific workplace. ${ }^{4}$ In order to know the characteristics of the individuals in this group, we ran a logistic regression analysis with Exit as the dependent variable $(1=$ working in the care sector but not in that workplace; $0=$ others). The results of the different models are presented in Table 3. As we can observe in Model 1, men intended to exit to a greater extent than women and, in Model 2, those with higher occupational status were more likely to exit, compared to those in the lower ranks of the hierarchy. The other control variables in Models 1 and 2 are not statistically significant.

In Model 2 and 3, the impact of trade union activity and the effect of the control variables that indicate the 'working conditions' of employees are examined, but none of the variables were significant.

In Models 4 and 5, as in the previous section, we examined the impact of the 'organisational context' variables on employees' decisions to leave the workplace instead of remaining. The results showed that employees' good relationship with their managers and friendly relationships with co-workers significantly decreased the likelihood of them intending to exit. It is worth noting that, when we took into consideration their relationship with their co-workers, the impact of the gender coefficient decreased, which means that the variable 'relationship with coworkers' partially explained men's higher propensity to exit.

Regarding the coefficient of occupational status, we can see that those with more trust in their managers in the higher job positions were more inclined to leave the organisation than others. One explanation may be that, in having a good relationship with their supervisors, these individuals were more confident than others that they would obtain a 'good recommendation' from their present boss. They were confident about changing their workplace as they could 
negotiate a higher salary - a phenomenon which is common in the Swedish labour market among those with professional occupations.

\section{Table 3 here}

Thus, an important result of this study was that being an employee from Africa, Asia or Latin America meant having a more negative view of the voice climate but not being more likely to plan for exit to a higher degree than others. Some foreign-born workers, especially those who had a professional occupation in their country of birth, saw working as an assistant nurse as an initial step towards completing their university education, especially if they wished to become fully-qualified nurses. Others tended to accept that this would be their work until retirement. Talking about the future and, despite having pursued other blue-collar craft educational paths, Informant 1 emphasised that she would prefer to do something else but 'For my part, I don't have so much to choose from. It's one thing if you have a higher education'. In the following quote by Informant 9, from the group of employees from Africa, Asia and Latin America, who ‘absolutely, absolutely... want[ed] to change job', a more expanded explanation was given for not seeking exit:

We immigrants are very frightened of not having a job. Now we have a job that makes us able to provide for our family... what if I lose my job or don't get any job if I leave? ... Many years ago I was talking to my teacher about why educated immigrants don't get jobs and untrained Swedes get jobs? She told me that there's discrimination in employment services, it's everywhere. Very skilled immigrants don't get the job they are trained for... They give the job to the Swedes and then to immigrants.

To summarise, even though workers from Africa, Asia and Latin America were less convinced than others of the benefits of voice behaviour, there was no difference between them and others in their intention to leave the organisation. In other words, despite their dissatisfaction, they were staying silent rather than exiting the workplace.

\section{Summary and discussion}

The first research question of this study was to determine which were the characteristics of the employees and features of the workplace (situational factors) that impacted on their perceptions of the voice climate. The second question asked how these characteristics and situational factors impacted on employees' views of the exit option.

Answering the first research question, the results show a significantly negative association between holding lower-ranked positions or being a member of the group of employees that has emigrated from a country in Africa, Asia or Latin America on the one hand and expressing a positive perception of voice climate on the other. Also, when the position factor was controlled for, employees from these continents were less likely than others to express positive perceptions of the voice climate. In response to the second question, while individuals in the lower-ranked positions had a lesser intention of exiting than others, there was no significant difference between the intention of workers born in Africa, Asia or Latin Americas and employees with other national backgrounds to leave the workplace. Concerning exit, the results also indicated that men (compared to women) had greater intentions of exiting, whereas there was no significant gender difference concerning voice. Thus, individuals who held lower-ranked positions and employees from Africa, Asia and Latin America were more likely than others to believe in strategies based on silence rather than on voice and exit. Furthermore, employees from those parts of the world were over-represented in lower-ranked positions at the workplace, with brings us to the third research question. 
Our third research question regards power differences as an explanation for these findings. Previous research has often either refrained from discussing the differences between majority and minority groups in voice behaviour as a question of power (Morrison, 2011: 393) or has speculated about 'differences in cultural values' (see Rank, 2009: 205). The results of our study, however, show that employees from Africa, Asia and Latin America hold lower ranks, earn less and experience less favourable relationships with their managers. These characteristics of their working life mean a lack of power, as defined by the research we introduced above: the lack of positional power (Islam and Zyphur, 2005), lower pay and, because of the less favourable relationships with their superiors, presumably also a lack of pleasure in work relations, the latter feature being part of Acker's (2006) definition of power.

These power differences seem to be a much more likely explanation for the disparity between employees born in Africa, Asia and Latin America and others in judging the voice climate than the difference in explanations of cultural value: these employees come from different parts of the world and have migrated for different reasons; that there would be common cultural factors that differentiated them from other foreign-born and native workers on this point seems unlikely. An overall more precarious situation in the labour market for the foreign-born than for natives might explain why employees in this group are not more likely than others to choose the exit option, although they trust the voice option less than others do. As explained by the informant we quoted above, these employees know that their situation is, on average, more precarious and they might fear discrimination when searching for a new job.

Research on the Swedish labour market indicates that employees from Africa, Asia and Latin America fare substantially worse in several respects than those native to Sweden or from other parts of Europe and North America (Behtoui and Neergaard 2011). These are also the employees who run the greatest risk of racialisation and discrimination. Although not developed in this article, some employees told us about the discriminatory behaviour of their superiors and co-workers, and some interviews with native employees indicated that they respected their foreign-born colleagues less than they did others (recall that respect was also an aspect of Acker's 2006 definition of 'power'). Thus we can conclude that there is an association between racialisation, power inequality in working life and the tendency towards silence rather than voice or exit.

While there remains a need for further research to substantiate and develop these results, especially in other sectors of the labour market, this study has pointed to yet another important problem caused by unequal power relations and racialisation at work. Those more disadvantaged who would have the most to gain from changing the situation might also be those who least believe in the possibility of attaining change by speaking up, and generally do not see exit as an alternative.

\section{Notes}

1. The excluded personnel are those who have some kind of administrative job or do not work frequently in the divisions.

2. The mean age of employees in this sector in Sweden is 45 years according to Wall (2013).

3. The share of part-time employed is 69 percent in the private sector and 63 percent in the municipal sector (Wall, 2013). About 28 percent of employees in the Swedish care sector had a temporary job contract in 2012 (Kommunal, 2012).

4. About 52 percent said that they would continue working in their current workplace, 7 percent were planning to leave the care sector and 7 percent were retiring within two 
years. Some planned to study further ( 7 percent) and 5 percent did not answer the question. 


\section{References}

Acker J (2006) Inequality regimes: gender, class, and race in organizations. Gender and Society 20(4): 441-464.

Allen M, Tuselmann H (2009) All powerful voice? The need to include exit, loyalty and neglect in empirical studies. Employee Relations 21(5): 538-552.

Behtoui, Alireza (2006) Unequal opportunities : the impact of social capital and recruitment methods on immigrants and their children in the Swedish labour market. Linköping: Department of Social and Welfare Studies Linköping University.

Behtoui, Alireza, and Anders Neergaard (2010) "Social capital and wage differentials between immigrants and natives." Work, Employment and Society 24(4):761-79.

Behtoui, Alireza, and Anders Neergaard (2011) "Social capital, status and income attainment in the workplace." International Journal of Sociology and Social Policy 32:42-55.

Boréus, Kristina, and Ulf Mörkenstam (2010) Spjälorna i buren : en arbetsplatsstudie av ojämlikhet mellan kvinnor och män, invandrade och infödda. Lund: Studentlitteratur.

Boréus, Kristina, and Ulf Mörkenstam (2015) "Patterned Inequalities and the Inequality Regime of a Swedish Housing Company." Nordic Journal of Working Life Studies 5(4):105-24.

Bouckaert G, Pollitt C (2011) Public Management Reform: A Comparative Analysis. New Public Management, Governance, and the Neo-Weberian State. Oxford: Oxford University Press.

Brinsfield CT (2009) Employee Silence: Investigation of Dimensionality, Development of Measures, and Examination of Related Factors. Ohio: The Ohio State University.

Burke RJ, Cooper CL (2013) Voice and Whistleblowing in Organizations: Overcoming Fear, Fostering Courage and Unleashing Candour. Cheltenham UK; Northampton USA: Edward Elgar.

Detert JR, Edmondson AC (2011) Implicit voice theories: taken-for-granted rules of selfcensorship at work. Academy of Management Journal 54(3): 461-488.

Detert, JR, Burris ER (2007) Leadership behavior and employee voice: is the door really open? Academy of Management Journal 50(4): 869-884.

Donaghey J, Cullinane N, Dundon T, Wilkinson A (2011) Reconceptualising employee silence: problems and prognosis. Work, Employment and Society 25(1): 51-67.

Erlandsson S, Storm P, Stranz A, Szebehely M, Trydegård GB (2013) Marketising trends in Swedish eldercare: competition, choice and calls for stricter regulation. In: Meagher G, Szebehely M (eds) Marketisation in Nordis Eldercare: A Research Report on Legislation, Oversight, Extent and Consequences. Stockholm: Stockholm University, Department of Social Work, 23-83.

Freeman RB, Medoff JL (1984) What Do Unions Do? New York: Basic Books.

Gustafsson RÅ, Szebehely M (2007) Privat och offentlig äldreomsorg: svenska omsorgsarbetares syn på arbetsmiljö och politisk styrning. Socialvetenskaplig Tidskrift 14(1): 47-66.

Hirschman AO (1970) Exit, Voice, and Loyalty: Responses to Decline in Firms, Organizations, and States. Cambridge Mass: Harvard University Press.

Holland P, Pyman A, Teicher J (2011) Employee voice and job satisfaction in Australia: the centrality of direct voice. Human Resource Management 50(1): 95-111.

Islam G, Zyphur MJ (2005) Power, voice, and hierarchy: exploring the antecedents of speaking up in groups. Group Dynamics: Theory, Research, and Practice 9(2): 93-103. 
Kanter RM (1993) Men and Women of the Corporation. New York: Basic Books.

Kjellberg A (2015) Kollektivavtalens täckningsgrad samt organisationsgraden hos arbetsgivar-förbund och fackförbund. Lund: Lund University, Department of Sociology, Research Report No. 2013: 1, updated 15. 05. 08.

Kommunal (2012) Vägval Välfärd. Available at : https://www.kommunal.se/PageFiles/142538/Rapport_Vagval_Valfard_121217.pdf

Laclau E (1990) New Reflections on the Revolution of Our Time. London: Verso.

Liang J, Farh CIC, Farh J-L (2012) Psychological antecedents of promotive and prohibitive voice: a two-wave examination. Academy of Management Journal 55(1): 71-92.

Marchington M, Wilkinson A (2005) Direct participation and involvement. In: Bach S (ed.) Managing Human Resources: Personnel Management in Transition. Oxford: Blackwell, 398-424.

McCall L (2001) Complex Inequality. Gender, Race and Class in the New Economy. New York: Routledge.

Meagher G, Szebehely M (2013) Four Nordic countries - four responses to the international trend of marketisation. In: Meagher G, Szebehely M (eds) Marketisation in Nordic Eldercare: A Research Report on Legislation, Oversight, Extent and Consequences. Stockholm: Stockholm University, Department of Social Work, 242-284.

Miles R (1993) Racism After 'Race Relations'. London: Routledge.

Milliken FJ, Morrison EW, Hewlin P (2003) An exploratory study of employee silence: issues that employees don't communicate upward and why. Journal of Management Studies 40(6): 1453-1476.

Morrison EW (2011) Employee voice behavior: integration and directions for future research. The Academy of Management Annals 5(1): 373-412.

Morrison EW, Wheeler-Smith SL, Kamdar D (2011) Speaking up in groups: a cross-level study of group voice climate and voice. Journal of Applied Psychology 96(1): 183-191.

Morrison EW, See EK, Caitlin P (2015) An approach-inhibition model of employee silence: the joint effects of personal sense of power and target openness. Personnel Psychology 68(3): 547-580.

Parker SK, Williams HM, Turner N (2006) Modeling the antecedents of proactive behavior at work. Journal of Applied Psychology 91(3): 636-652.

Rank J (2009) Challenging the status quo. In: Özbilgin M (ed.) Equality, Diversity and Inclusion at Work: A Research Companion. Cheltenham: Edward Elgar, 195-215.

Solomos J (2002) Race and Racism in Britain. Basingstoke: Macmillan.

Sörensdotter R (2008) Omsorgsarbete i Omvandling: Genus, Klass och Etnicitet inom Hemtjänsten. Göteborg; Stockholm: Makadam.

SCB (2015) Trends for Persons in Temporary Employment. AM 110 SM 1501. Stockholm: Statistics Sweden.

Strauss G (2006) Worker participation: some under-considered issues. Industrial Relations 45(4): 778-803.

Svensson LG, Eriksson UY ( 2009) Yrkesstatus. En Sociologisk Studie av Hur Yrken Uppfattas och Värderas. Gothenburg: Gothenburg University, Department of Sociology, Research Report No. 140.

Wall A (2013) Visstid på Livstid? En Rapport om de Otrygga Anställningarna. Stockholm: Kommunal.

Wilkinson A (2012) The Oxford Handbook of Participation in Organizations. Oxford: Oxford University Press.

Wilkinson, A, Fay C (2011) New times for employee voice? Human Resource Management 50(1): 65-74. 
Table 1. Summary of sample characteristics (percent or mean)

\begin{tabular}{|c|c|c|c|c|}
\hline Origin & Sweden & $\begin{array}{c}\text { North- } \\
\text { Western } \\
\text { Europe/ } \\
\text { North } \\
\text { America }\end{array}$ & $\begin{array}{l}\text { Eastern } \\
\text { Europe }\end{array}$ & $\begin{array}{c}\text { Africa/Asia/ } \\
\text { Latin } \\
\text { America }\end{array}$ \\
\hline Percent of total & 66.4 & 2.8 & 4.5 & 26.3 \\
\hline Age & 46.6 & 55.6 & 47.4 & 44 \\
\hline Gender - men (\%) & 11 & 25 & 15 & 12 \\
\hline Years of education & 12.7 & 13.8 & 13.6 & 12.6 \\
\hline Job experience, general (years) & 28 & 36 & 28 & 25 \\
\hline Active in trade union (\%) & 30 & 32 & 27 & 28 \\
\hline Permanent tenure (\%) & 91 & 100 & 100 & 91 \\
\hline Private sector (\%) & 12 & 13 & 15 & 17 \\
\hline Income/months, adjusted for work hours (SEK) & 27,301 & 27,509 & 25,450 & 24,038 \\
\hline $\begin{array}{l}\text { Assistant nurses (vårdbiträde + undersköterska) } \\
(\%)\end{array}$ & 70.3 & 37.5 & 61.5 & 93.4 \\
\hline Occupational status & 37 & 43 & 36 & 32 \\
\hline Good relationship with superior (mean) & 3.4 & 3.5 & 3.5 & 3.1 \\
\hline Superior trustable (mean) & 3.4 & 3.7 & 3.4 & 3.0 \\
\hline
\end{tabular}


Table 2. Association between the different individual and situational factors and how the voice climate is judged

\begin{tabular}{|c|c|c|c|c|c|}
\hline & Model 1 & Model 2 & Model 3 & Model 4 & Model 5 \\
\hline Gender (men) & $\begin{array}{r}-.150 \\
(-.048) \\
\end{array}$ & $\begin{array}{r}-.215 \\
(-.069) \\
\end{array}$ & $\begin{array}{r}-.244 \\
(-.078) \\
\end{array}$ & $\begin{array}{r}-.176 \\
(-.056)\end{array}$ & $\begin{array}{r}-.140 \\
(-.045) \\
\end{array}$ \\
\hline \multicolumn{6}{|l|}{ Region of birth } \\
\hline $\begin{array}{l}\text { North-Western Europe/North } \\
\text { America }\end{array}$ & $\begin{array}{r}-.017 \\
(-.003)\end{array}$ & $\begin{array}{r}-.058 \\
(-.010)\end{array}$ & $\begin{array}{r}-.060 \\
(-.010)\end{array}$ & $\begin{array}{r}-.189 \\
(-.033)\end{array}$ & $\begin{array}{r}-.163 \\
(-.029)\end{array}$ \\
\hline Eastern Europe & $\begin{array}{r}-.100 \\
(-.019) \\
\end{array}$ & $\begin{array}{r}-.022 \\
(.004) \\
\end{array}$ & $\begin{array}{r}.040 \\
(.008) \\
\end{array}$ & $\begin{array}{r}-.117 \\
(-.023) \\
\end{array}$ & $\begin{array}{r}-.116 \\
(-.022) \\
\end{array}$ \\
\hline Africa/Asia/Latin America & $\begin{array}{r}-.470 * * \\
(-.207)\end{array}$ & $\begin{array}{r}-.356 * * \\
(-.157)\end{array}$ & $\begin{array}{r}-.348 * * \\
(-.154)\end{array}$ & $\begin{array}{l}-.223 * \\
(-.098)\end{array}$ & $\begin{array}{r}-.211 * * \\
(-.093)\end{array}$ \\
\hline Work experience & & $\begin{array}{r}-.008 \\
(-.086)\end{array}$ & $\begin{array}{r}-.009 \\
(-.102)\end{array}$ & $\begin{array}{r}-.010 \\
(-.117)\end{array}$ & $\begin{array}{l}-.011 * \\
(-.122)\end{array}$ \\
\hline Occupational status & & $\begin{array}{r}.027 * * \\
(.260)\end{array}$ & $\begin{aligned} .025 * * \\
(.244)\end{aligned}$ & $\begin{array}{l}.009 * \\
(.086)\end{array}$ & $\begin{array}{l}.010 * \\
(.098)\end{array}$ \\
\hline Union & & $\begin{array}{r}-.039 \\
(-.018) \\
\end{array}$ & $\begin{array}{r}-.029 \\
(-.013)\end{array}$ & $\begin{array}{r}.074 \\
(.033) \\
\end{array}$ & $\begin{array}{r}.072 \\
(.033) \\
\end{array}$ \\
\hline Permanently employed & & & $\begin{array}{r}.090 \\
(.026) \\
\end{array}$ & $\begin{array}{r}.130 \\
(.037) \\
\end{array}$ & $\begin{array}{r}.120 \\
(.035) \\
\end{array}$ \\
\hline Sector (private) & & & $\begin{array}{r}.186 \\
(.063) \\
\end{array}$ & $\begin{array}{r}.068 \\
(.023) \\
\end{array}$ & $\begin{array}{r}.051 \\
(.017) \\
\end{array}$ \\
\hline Full-/Part-time & & & $\begin{array}{r}.005 \\
(.067) \\
\end{array}$ & $\begin{array}{r}-.002 \\
(-.022) \\
\end{array}$ & $\begin{array}{r}-.002 \\
(-.023) \\
\end{array}$ \\
\hline Relationship with superior & & & & $\begin{array}{r}.604 * * \\
(.602)\end{array}$ & $\begin{array}{r}.572 * * \\
(.570)\end{array}$ \\
\hline Relationship with co-worker & & & & & $\begin{array}{l}.109 * \\
(.109 \\
\end{array}$ \\
\hline$R^{2}$ adj. & .03 & .10 & .10 & .43 & 0.44 \\
\hline
\end{tabular}

$* *$ denotes significance at $1 \%$ level, * at $5 \%$ level. 
Table 3. Odds of being a member of the 'Exit' group, ' $\operatorname{Exp}(\mathrm{B})-1$ ' and (SE)

\begin{tabular}{|c|c|c|c|c|c|}
\hline & Model 1 & Model 2 & Model 3 & Model 4 & Model 5 \\
\hline Gender (men) & $\begin{array}{r}1.64 * * \\
(.39) \\
\end{array}$ & $\begin{array}{r}1.47^{*} \\
(.40)\end{array}$ & $\begin{array}{c}1.45^{*} \\
(.40)\end{array}$ & $\begin{array}{r}\text { 1.42* } \\
(.42)\end{array}$ & $\begin{array}{r}1.27 * \\
(.42)\end{array}$ \\
\hline \multicolumn{6}{|l|}{ Region of birth } \\
\hline North-Western Europe/North America & $\begin{array}{r}-.61 \\
(1.1)\end{array}$ & $\begin{array}{r}-.56 \\
(1.1)\end{array}$ & $\begin{array}{r}-.57 \\
(1.1)\end{array}$ & $\begin{array}{r}-.53 \\
(1.1)\end{array}$ & $\begin{array}{r}-.55 \\
(1.1)\end{array}$ \\
\hline Eastern Europe & $\begin{array}{l}1.88 \\
(.64)\end{array}$ & $\begin{array}{r}2.36 \\
(.65)\end{array}$ & $\begin{array}{r}2.4 \\
(.65)\end{array}$ & $\begin{array}{r}2.6 \\
(.65)\end{array}$ & $\begin{array}{r}2.6 \\
(.66)\end{array}$ \\
\hline Africa/Asia/Latin America & $\begin{array}{r}-.02 \\
(.33)\end{array}$ & $\begin{array}{r}.09 \\
(.35)\end{array}$ & $\begin{array}{r}.11 \\
(.36)\end{array}$ & $\begin{array}{r}.03 \\
(.36)\end{array}$ & $\begin{array}{r}.03 \\
(.37)\end{array}$ \\
\hline Work experience & & $\begin{array}{r}-.02 \\
(.014)\end{array}$ & $\begin{array}{r}-.02 \\
(.015)\end{array}$ & $\begin{array}{r}-.02 \\
(.015)\end{array}$ & $\begin{array}{r}-.02 \\
(.015)\end{array}$ \\
\hline Occupational status & & $\begin{array}{l}.028 * \\
(.014)\end{array}$ & $\begin{array}{l}.028 * \\
(.015)\end{array}$ & $\begin{array}{l}.038 * \\
(.016)\end{array}$ & $\begin{array}{l}\mathbf{. 0 3 4} \\
(.016)\end{array}$ \\
\hline Union & & $\begin{array}{r}-.20 \\
(.35)\end{array}$ & $\begin{array}{r}-.20 \\
(.21)\end{array}$ & $\begin{array}{r}-.34 \\
(.35)\end{array}$ & $\begin{array}{r}-.33 \\
(.35)\end{array}$ \\
\hline Permanently employed & & & $\begin{array}{r}-.07 \\
(.50)\end{array}$ & $\begin{array}{c}-.02 \\
(.50)\end{array}$ & $\begin{array}{r}-.17 \\
(.50)\end{array}$ \\
\hline Sector (private) & & & $\begin{array}{r}-.04 \\
(.43)\end{array}$ & $\begin{array}{r}-.06 \\
(.44)\end{array}$ & $\begin{array}{r}.05 \\
(.44)\end{array}$ \\
\hline Full-/Part-time & & & $\begin{array}{r}.002 \\
(.013)\end{array}$ & $\begin{array}{r}.005 \\
(.014)\end{array}$ & $\begin{array}{r}.003 \\
(.013)\end{array}$ \\
\hline Relationship with superior & & & & $\begin{array}{r}-0.27 * \\
(.15)\end{array}$ & $\begin{array}{c}-.20^{*} \\
(.16)\end{array}$ \\
\hline Relationship with co-worker & & & & & $\begin{array}{r}-.25^{* *} * \\
(.16)\end{array}$ \\
\hline Log likelihood & 296 & 289 & 288 & 284 & 281 \\
\hline Pseudo $R^{2}$ & .05 & .085 & .086 & .107 & .124 \\
\hline
\end{tabular}

** denotes significance at $1 \%$ level. * at $5 \%$ level. 